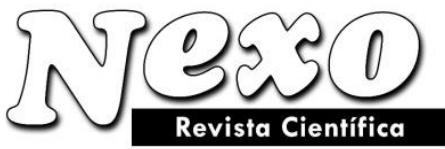

ISSN-E 1995-9516

Universidad Nacional de Ingeniería COPYRIGHT @ (UNI). TODOS LOS DERECHOS RESERVADOS

http://revistas.uni.edu.ni/index.php/Nexo https://doi.org/10.5377/nexo.v34i06.13158

\title{
Nucleation under the impact of pulsed laser radiation
}

\section{Nucleación bajo el impacto de la radiación láser pulsada}

\author{
Sergey Nikoloaevich Maksimovsky*, Aleksey Urievich Stavtsev \\ K.G. Razumovsky Moscow State University of technologies and management (the First Cossack \\ University). Moscow, Russian Federation. \\ *Corresponding author E-mail: s.n.maksimovsky@ mail.ru
}

(recibido/received: 28-octubre-2021; aceptado/accepted: 07-diciembre-2021)

\begin{abstract}
The article shows theoretical calculations of nucleation in nonequilibrium conditions under the impact of high-power laser radiation, and their experimental confirmation. The phase transition during homogeneous nucleation without seed in the gas phase has long been studied by various scientists in the developed countries of the world. Several nucleation theories have been developed, however, they are difficult or impossible to apply to fast-flowing crystallization processes occurring at high pressures and temperatures that take place when using high-power laser radiation in the gas phase. In this article, an extended model of nucleation in the gas phase is developed using traditional thermodynamic concepts, as well as the influence of the process conditions on the equilibrium concentration and the formed particle size within the range from $100 \mathrm{~nm}$ to 1 micron is predicted. The article describes experiments on growing structures on plastic substrates containing inside optical inhomogeneities in the form of diffraction gratings. The calculation of the sublimation evaporation pressures of aluminum is conducted depending on different laser radiation power densities. The authors obtained images of nascent structures by electron microscopy and demonstrated the possibility of observing the nucleation phases in situ by changing the power of laser radiation of the sample.
\end{abstract}

Keywords: Whiskers; Crystallization; Gibbs energy; Critical radius of the nucleus; Polycarbonate; Diffraction grating.

\section{RESUMEN}

El artículo muestra cálculos teóricos de nucleación en condiciones de no equilibrio bajo el impacto de radiación láser de alta potencia y su confirmación experimental. La transición de fase durante la nucleación homogénea sin semilla en la fase gaseosa ha sido estudiada durante mucho tiempo por varios científicos en los países desarrollados del mundo. Se han desarrollado varias teorías de nucleación, sin embargo, son difíciles o imposibles de aplicar a procesos de cristalización de flujo rápido que ocurren a altas presiones y temperaturas que tienen lugar cuando se usa radiación láser de alta potencia en la fase gaseosa. En este artículo, se desarrolla un modelo extendido de nucleación en fase gaseosa utilizando conceptos termodinámicos tradicionales, así como se predice la influencia de las condiciones del proceso en la concentración de equilibrio y el tamaño de partícula formada dentro del rango de $100 \mathrm{~nm}$ a 1 micra. El artículo describe experimentos sobre estructuras en crecimiento en sustratos plásticos que contienen inhomogeneidades ópticas internas en forma de rejillas de difracción. El cálculo de las presiones de 
evaporación por sublimación del aluminio se realiza en función de las diferentes densidades de potencia de radiación láser. Los autores obtuvieron imágenes de estructuras nacientes mediante microscopía electrónica y demostraron la posibilidad de observar las fases de nucleación in situ cambiando la potencia de radiación láser de la muestra.

Palabras claves: Whiskers; Cristalización; Energía de Gibbs; Radio crítico del núcleo; Policarbonato; Rejilla de difracción.

\section{INTRODUCTION}

The phase transition during homogeneous nucleation without seed in the gas phase has long been studied by various scientists in the developed countries of the world (Christian, 1962; Hirths and Pound, 1966; Turnball, 1956). Several theories of nucleation have been developed (Laudise, 1970; Myerson and Ginde, 2002; McGinty et al., 2020; Parker, 1970), however, they are difficult or impossible to apply to fast-flowing crystallization processes occurring at high pressures and temperatures that take place when using highpower laser radiation in the gas phase.

\section{METHODS}

Let us consider a classical gas-phase system in which the molecules are separated from each other at a relatively large distance of $3^{*} 10^{-9} \mathrm{~m}$ at a pressure of $10^{5} \mathrm{~Pa}$. The atoms and molecules in the gas phase are arranged randomly, and the entropy of such a gas is maximum. When transiting to a liquid, the atoms and molecules are separated from each other at a distance of $\sim 10^{-10} \mathrm{~m}$ and a short-range ordering occurs, which extends over several tens of diameters of atoms and molecules (Christian, 1965; Zhao et al., 2012).

The first question that arises is what happens to atoms and molecules that are exposed to a short-term high temperature of $3000-5000^{\circ} \mathrm{C}$ and a pressure of more than $10^{10} \mathrm{~Pa}$ when subjected to pulsed laser radiation with power densities of $0.3-943 \mathrm{MW} / \mathrm{cm}^{2}$ in a closed system.

The appearance of a small drop with a radius $r$ at a vapor pressure $p$, while the equilibrium pressure of the crystallizing component is $p_{0}$ (at temperature $T$ ) will lead to a change in the Gibbs free energy (Danielli $e t$ al., 1970)

$\Delta G=\Delta G_{\text {об. }}+\Delta G_{\text {пов. }}$

where $\Delta G_{\text {sur }}$ is the change in the surface energy, and $\Delta G_{\mathrm{vol}}$ is the change in the volumetric free energy during condensation of pure $\mathrm{Al}$, where the value refers to a single atom and is equal to $\Delta G_{o \sigma .}=-k T \ln \frac{p}{p_{0}} G_{v o l}=\ldots$.

( $k$ is the Boltzmann constant, $T$ is the temperature, $p_{0}$ is the equilibrium pressure of the crystallized substance, $p$ is the pressure during the sublimation evaporation of aluminum in our experiment) since it refers to the change in free energy during isothermal compression.

For a spherical drop with radius $r$, we get

$\Delta G_{\text {об. }}=-\frac{4}{3} \pi \frac{r^{3}}{v^{\ell}} \times k T \ln \frac{p}{p_{0}}, \Delta G_{v o l}=\ldots$ 
where $v^{\ell}$ is the atomic volume of the liquid, so we take this value to be constant. This value $\Delta G_{\text {nов. }}^{\text {npocm. }}$ $\Delta \mathrm{G}_{\text {sur }}{ }^{\text {simp }}$ is equal to $4 \pi r^{2} \gamma_{L V}$, where $\gamma_{L V}$ is the free energy of the liquid-vapor interface. Wherefrom we get

$$
\Delta G=4 \pi r^{2} \gamma_{L V}-\frac{4 \pi r^{3}}{3 v^{\ell}} k T \ln \frac{p}{p_{0}}
$$

Since the first term is $\sim r^{2}$, and the second term is $\sim r^{3}$, then for a sufficiently small $r$, the first term prevails and in this case $\Delta G_{\text {nов. }}^{\text {nрос. }} \Delta \mathrm{G}_{\text {sur }}$ simp is positive, while for sufficiently large $r$, the second term prevails, and in this case, $\Delta G$ takes a negative value. Denote the value of the critical $\Delta G$ by $\Delta G_{c r}$ which in this case represents an activation barrier for the nucleus origin

$$
r_{\kappa p .}=\frac{2 v^{\ell} \gamma_{L V}}{k T \ln p / p_{0}} \cdot r_{c r}=\ldots \ldots
$$

Let's estimate what is the pressure value $p$ during the process. Hence it follows that

$$
\Delta G_{\kappa p .}=\frac{16\left(v^{e}\right)^{2} \gamma_{L V}^{3}}{3\left[k T \ln \left(p / p_{0}\right)\right]^{2}}<0 \cdot G_{c r}=\ldots \ldots
$$

When $r<<r_{\text {cr }}$ the nucleus will evaporate and the seeding will not occur, while when $r>r_{\text {cr }}$ the nucleus will start growing.

When growing coherent nanowhiskers (Maximovsky et al., 2018, 2019) at a pressure of more than 100,000 atm, the value $k T \ln p / p_{0}$ makes the main contribution to the $\Delta G_{\mathrm{cr}}$, and $\Delta G_{\mathrm{cr}}$ will be a negative value, which will contribute to a high rate of embryo formation compared to known theories. Therefore, according to the theory of the Nobel Prize winner Townes (Chao et al., 1968; Townes, 1964), the laser beam will arrange the locations of the nuclei. In other words, the entropy of the system will decrease.

According to the works of G.A. Askaryan (1962), the particles of the formed nuclei will be pushed to the periphery of the laser beam.

The radiation flux of laser intensities, in addition to the actual pressure of electromagnetic radiation, also causes sublimation evaporation, whose pressure exceeds the light pressure by several orders of magnitude (Askaryan and Moroz, 1962; Chao et al., 1968; Eshkin, 1973; Townes, 1964).

When powerful laser radiation is applied to a matter under rapid heating, the matter starts evaporating, forming pressure that is orders of magnitude higher than the laser radiation pressure itself $p_{\Im / M}=\frac{I}{c}(1-T+R), p_{e-m}=\ldots$ where $I$ is the energy flux density (intensity), $T$ and $R$ are the transmission and reflection coefficients, respectively, $c$ is the light velocity in a vacuum. Sublimation evaporation causes an increase in pressure to $10^{11} \mathrm{~Pa}$.

The formula for estimating the pressure created by the evaporated matter is known from the works of Townes (Townes, 1964; Chao et al., 1968) and Askaryan (Askaryan and Moroz, 1962): $p \approx \frac{\alpha I v_{u}}{\lambda}$. Here, $\alpha$ is the fraction of energy converting into evaporation (for high power beams and absorbing target substances 
this value can be considered approximately equal to one (Askaryan and Moroz, 1962; Eshkin, 1973)), I is the beam intensity (energy flux density), $v_{u}$ is the velocity of the ejected particles that create pressure, the parameter $\lambda \sim \lambda_{0}+\frac{1}{2} v_{u}^{2}$ is the sum of the specific heat of sublimation evaporation of the matter and the specific energy for accelerating its vapors.

In this regard, it was necessary to estimate the pressure values in this cavity depending on the parameters of laser radiation.

a)
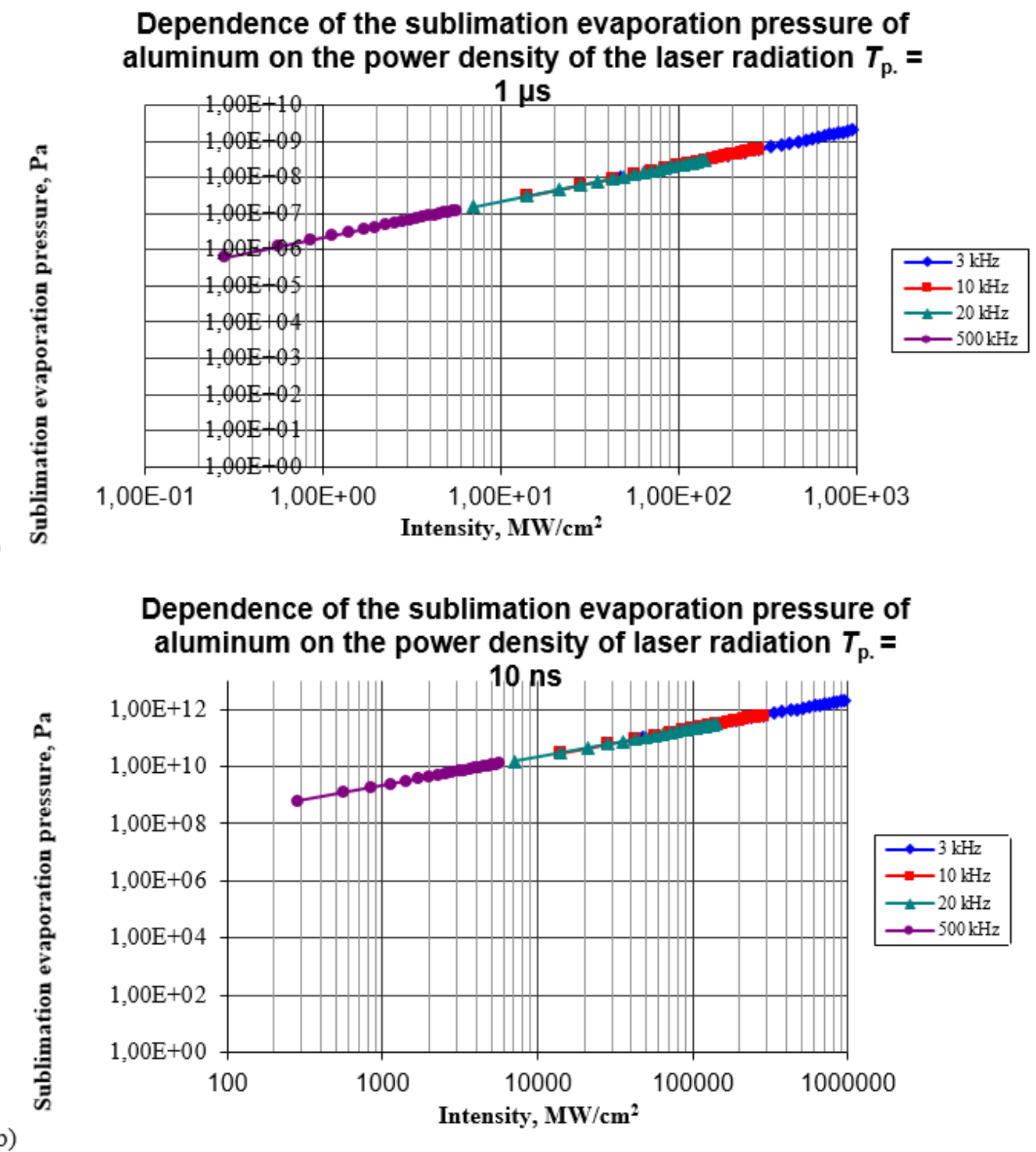

Figure 1. Dependence of the pressure of sublimation evaporation of aluminum vapors within the range of average power $1-20 \mathrm{~W}$, beam diameter $30 \mu \mathrm{m}$ at a pulse duration $1 \mu \mathrm{s}(\mathrm{a})$, and $10 \mathrm{~ns}$ (b).

\section{EXPERIMENT}

The article investigates the effect of pulsed laser radiation on composite polymer substrates containing two diffraction gratings in a polycarbonate layer based on 2,2-bis (4-hydroxyphenyl) propane. The thickness of 
the polycarbonate is $0.6 \mathrm{~mm}$, and the space between the gratings 5 microns thick is filled with optically transparent glue. The period of diffraction gratings is 0.74 microns. The substrate sample surfaces were metalized with a layer of aluminum foil (Figure 2).

The substrates, i.e. composite material samples, were irradiated with pulsed focused laser radiation from a solid-state Nd:YAG laser with a wavelength of 1.064 microns operating in the pulse-periodic mode of modulated Q-factor with an average power of $20 \mathrm{~W}$. The pulse repetition frequency was $3 \mathrm{kHz}$, and the pulse duration was $\sim 10 \mathrm{~ns}$.

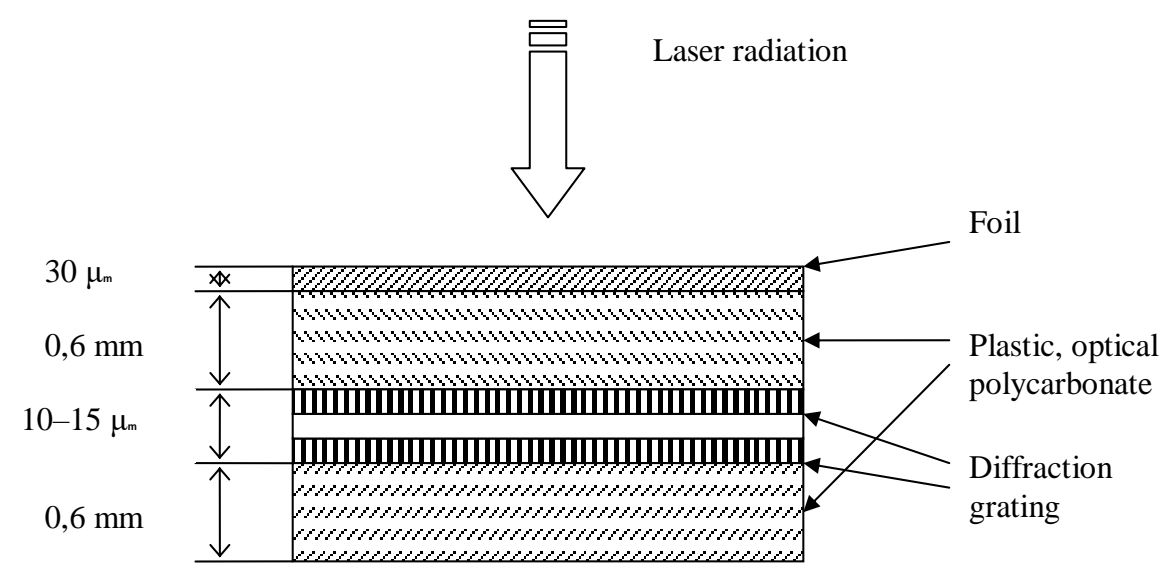

Figure 1. Schematic arrangement of a composite material sample with two diffraction gratings (not scaled).

Thus, when irradiating such an object, a closed cavity with a controlled redox medium is formed between two layers of polycarbonate or the upper foil layer and the substrate, depending on the material being crystallized, in which the pressure reaches more than $10^{10} \mathrm{~Pa}$ and the temperature $\sim 4000^{\circ} \mathrm{C}$ for $10-100 \mathrm{~ns}$, during which heat does not have time to dissipate (Bogonosov and Maksimovskii, 2011).

\section{RESULTS}

After irradiation, the inner part of the substrate between the diffraction gratings was studied using an electron microscope DSM-7001F (manufactured by JEOL, Japan), as well as the equipment provided by the Shared Facility Center at P. N. Lebedev Physical Institute of RAS.

In Figure 3, structures with sizes of 10-50 microns can be observed, as well as fractions of smaller droplets up to 10 microns, regularly located at distances of about 150 microns. Some objects are single, some have the form of double drops, from which growth begins. Besides, there are pairs of drops that are approaching but have not yet united. According to the X-ray analysis, the droplets are made of aluminum. 


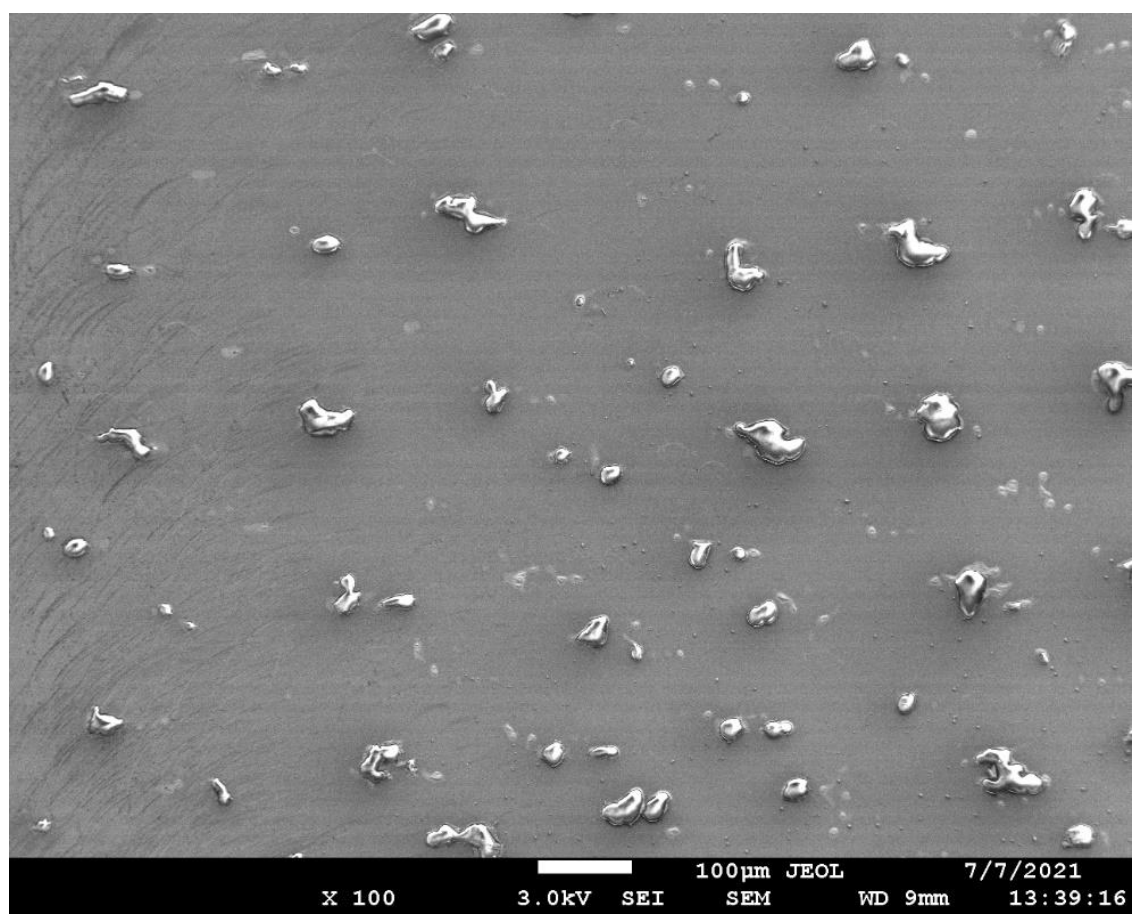

Figure 3. Nucleation dynamics of regularly spaced aluminum structures. Electron microscope JSM-7001F (JEOL, Japan).

Thus, in an experiment conducted using a single substrate, changing the irradiation power, it is possible to capture the successive stages of the nucleation process in situ.

\section{CONCLUSION}

It is shown that thermodynamics, being a basic theory, allows describing the nucleation in the whisker growing process. At that, calculations show that these processes occur at high sublimation evaporation temperatures and pressures.

By changing the radiation power, it is possible to obtain a consistent picture of the in situ nucleation process on a single substrate.

The obtained results allow applying the proposed technology for the crystallization of metals, semiconductors, and multi-component compounds (shattuckite) (Maximovskii et al., 2016). As a result, technology has been created to protect plastic cards and identification documents that have non-reproducible visual signs that are easily detected by the naked eye: three signs on plastic and four on glass.

\section{ACKNOWLEDGMENTS}

Authors acknowledge the Shared Facility Center at P. N. Lebedev Physical Institute of RAS for using their equipment.

\section{FINDINGS}

The reported study was funded by the Russian Foundation for Basic Research (RFBR), project No. 19-32$90063 \backslash 19$. 


\section{REFERENCES}

Askaryan, G. A. (1962). The effect of the field gradient of an intense electromagnetic beam on electrons and atoms. Journal of Experimental and Theoretical Physics, 42 (6), 1567-1570.

Askaryan, G. A. and Moroz, E. P. (1962). Pressure during evaporation of a substance in a radiation beam. Journal of Experimental and Theoretical Physics, 43 (6), 2319-2320.

Bogonosov, K. A. and Maksimovskii, S. N. (2011). High-speed nanocrystallization of copper in lowtemperature laser plasma. Doklady Physics, $56 \quad$ (8), 419-422. http://dx.doi.org/10.1134/S1028335811080052

Chao, R., Gaimar, E. and Townes, Ch. (1968). Self-focusing of the optical maser beam. In: Collection of articles "The effect of laser radiation" (p. 187). Translated from English by Yu.P. Raiser. Moscow, Russia: Mir.

Christian, J. W. (1962). The theory of transformation. Amsterdam.

Christian, J. W. (1965). The theory transportations in metals and alloys. Oxford, UK: Pergamon Press.

Danielli, J. F., Riddiford, A. C. and Resenberg, M. D. (Eds.). (1970). Recent progress in surface science. Vol. 3. New-York, NY; London, UK: Academic Press, p. 23.

Eshkin, A. (1973). Pressure of laser radiation. Successes of Physical Sciences, 110 (1), 101-116.

Hirths, J. P. and Pound, G. M. (1966). Evaporation and condensation. Translated from English by Yu. A. Sapozhnikov. Moscow, Russia: Metallurgia.

Laudise, R. A. (1970). The growth of single crystals. Murray Hill, NJ: Bell Telephone Laboratories.

Maximovskii, S., Turyanskiy, A., Bogonosov, K., Gizha, S., Senkov, V. and Pirshin, I. (2016). Shattuckite synthesis and the pattern formation by the scanning laser beam. Tecnologia em Metalurgia Materiais e Mineração, 13 (3), 248-251. http://dx.doi.org/10.4322/2176-1523.0988

Maximovsky, S. N., Stavtsev, A. Yu. and Ivanova, V. N. (2018). Nanowhiskerography - a new method of security printing using scanning laser radiation. Bulletin of the Lebedev Physics Institute, 45 (11), 341-345.

Maksimovsky, S. N., Stavtsev, A. Yu. and Ovsyannikova, A. V. (2019). Growth of coherent whiskers on polycarbonate substrates by laser radiation. Journal of Russian Laser Research, 40 (2), 197-204.

McGinty, J., Yazdanpanah, N., Price, Ch., ter Horst, J. H. and Sefcik, J. (2020). Nucleation and crystal growth in continuous crystallization. In: N. Yazdanpanah and Z. K Nagy (Eds.), The handbook of continuous crystallization (pp. 1-50). London, UK: The Royal Society of Chemistry. http://dx.doi.org/10.1039/9781788013581-00001

Myerson, A. S., and Ginde, R. (2002). Crystals, crystal growth, and nucleation. In: A. S. Myerson (Ed.), Handbook of Industrial Crystallization (2nd ed., pp. 33-65). Boston, MA: Butterworth-Heinemann. 
Parker, R. L. (1970). Crystal growth mechanisms: Energetics, kinetics, and transport. In: H. Ehrenreich, F. Seits and D. Turnbull (Eds.), Solid-state physics (Vol. 25, pp. 151-299). New York, NY; London, UK: Academic Press.

Townes, Ch. H. (1964). The structure laser light. Physics Letters, 13, 479.

Turnball, D. (1956). Phase Changes. Solid State Physics, 3, 225-306.

Zhao, J., Miao, H., Duan, L., Kang, Q. and He, L. (2012). The mass transfer process and the growth rate of $\mathrm{NaCl}$ crystal growth by evaporation based on temporal phase evaluation. Optics and Lasers in Engineering, 50 (4), 540-546. 